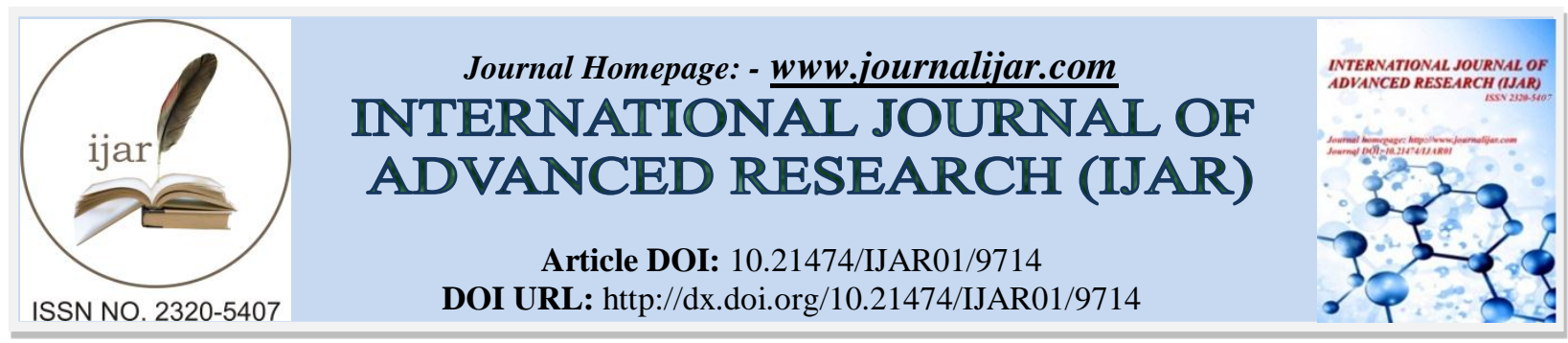

RESEARCH ARTICLE

\title{
THE IMPACT OF SUSTAINABILITY-DRIVEN ENTREPRENEURIAL EDUCATION ON THE ENTREPRENEURIAL CAREER OF FEMALE UNDERGRADUATES IN STEM AND MANAGEMENT FIELDS.
}

Dr. Kalpana R. Ambepitiya and D. Dushanthi Lokuge.

Department of Management and Finance, General Sir John Kotelawala Defence University, Sri Lanka.

\section{Manuscript Info}

Manuscript History

Received: 08 July 2019

Final Accepted: 10 August 2019

Published: September 2019

Key words:-

Attitudes, Entrepreneurial Competence, Innovation Skills, Management Field, STEM Fields, Sustainability-driven Entrepreneurial Education.

\begin{abstract}
The purpose of this study is to identify exactly how higher education programmes in Management and STEM strengthen the entrepreneurial competence and innovation skills of the female students while changing their attitudes positively towards choosing a sustainable entrepreneurial career. This paper explains the impact that sustainability-driven entrepreneurial education programmes have on guiding female students in the fields of Management and STEM to select a sustainable entrepreneurship career. A descriptive and logistic regression methodology has been used for this study. The sample group comprised female undergraduates in the STEM and Management fields. This study was carried out over a period of four months and used a questionnaire as the survey instrument. The outcome of this study concludes that Sustainability-driven entrepreneurial education is effective for both STEM and Management fields. The main differences found were that innovation skills development was not very popular among female Management students while interest in entrepreneurial competence development was low among STEM female students.
\end{abstract}

Copy Right, IJAR, 2019,. All rights reserved.

\section{Introduction:-}

The importance of developing women's entrepreneurial capabilities is acknowledged by all progressive thinkers and the topic has continued to attract the world's attention. In fact, the number of women entrepreneurs and women decision makers is an important indicator of gender representation in the economy and it is also used in economic policy making (Shinnar et al., 2018). Women in business are able to change the conservatism of traditional business and make it more modern by owning and running businesses in many fields (Huan, 2017). By doing this they demonstrate their abilities in entrepreneurship while enjoying economic independence too. This paper paid special attention to the Management, Science, Technology, Engineering and Mathematics subjects because many researchers have observed that women are underrepresented in the Science, Engineering and Technology fields (Cooper \& McGowan, 2009). The knowledge intensive disciplines of Science, Technology, Engineering and Mathematics (STEM) and Management are considered as the crucial underpinnings that are essential for the generation of innovation and economic growth. Research, development and new venture creation in these areas not only fuel productivity but also help build the so-called knowledge economy (Henry et al., 2010). Therefore, the authors consider that the emergence of women entrepreneurs in the STEM fields is as important as the emergence of women entrepreneurs in Management. How university education is systematically establishing new academic programmes to train more women entrepreneurs in these fields to meet future demands is an interesting topic that is

Corresponding Author:-Dr. Kalpana R. Ambepitiya.

Address:-Department of Management and Finance, General Sir John Kotelawala Defence University, Sri 
worthy of investigation. The authors see university programmes focused on students as a solution to the constraints of training and development. In Sri Lanka, there are entrepreneurship based undergraduate and postgraduate degree programmes offered by both private and state universities, some of which are affiliated with foreign institutes (University Grants Commission of Sri Lanka, 2016). Majority of these programmes were designed to cater to management students (Balasundaram, 2010) while a few programmes allow STEM students also to get enrolled. The curriculum of some of these programmes is designed to reflect the emerging trends in business, while the other programmes impart knowledge on the basics of entrepreneurship.

The economic status of women is not only an economic concern but also a social and environmental concern. To achieve all these, the education programmes on entrepreneurship development must play a big role to enhance the competencies of female undergraduates. Focusing on female students, entrepreneurial competencies like business knowledge, innovation skills and intricacies of starting up a business are included in the undergraduate programmes. According to university statistics, the female undergraduate recruitments to the fields of Science, Technology, Engineering and Mathematics in Sri Lanka increased by 21\% in 2016 (4\% in 2015) while the female graduate recruitments to the management field were at a lower level than the STEM recruitments, and showed only a 5\% increase in 2016 (4\% in 2015). Management discipline educates students to perform management roles needed for running an organization, such as exercising business initiatives and thinking up business strategies. In view of this, the authors are following the direction pointed out by Rauch and Hulsink (2015) by doing more research on specific types of entrepreneurial education pursued by students from the different disciplines. By doing that the authors expect to fill the gaps in understanding of what constitutes effective female entrepreneurial education (Ahmed et al., 2017) in the field of Management (Schmitt-Figueiro \& Raufflet, 2015) and STEM (Rose et al., 2015), and more particularly, sustainable entrepreneurship education (Ramos et al., 2015) Therefore, the findings of this paper are expected to contribute towards further development of sustainable entrepreneurial education in the higher education institutes of developing countries.

\section{Literature}

This section begins by describing in detail the sustainable entrepreneurial education programmes offered to the female students following STEM and Management courses. The role of sustainability-driven entrepreneurship is discussed in the literature by addressing entrepreneurial competence, attitudes, innovation skills, and entrepreneurship education for sustainability, which is endorsed as the conceptual framework of the study. A hypothesis is proposed after discussing the link between the variables. The integration of sustainable development into university education is viewed by some scholars as a sign of the emergence of sustainable universities (Ramos et al., 2015). The conceptual framework of this study is focused on finding evidence on the effectiveness of sustainability-driven entrepreneurship education offered to female undergraduates, differentiating it from the traditional type of study.

According to Unger et al. (2013), the successful entrepreneurs were empowered by the skills and competencies they had acquired when they founded the firms but Kuratko (2005) and Bae et al. (2014) have declared that these skills and competencies are defined by the education. Entrepreneurial education has continued to evolve and contribute to different fields including management, technical studies and other disciplines (Davidsson, 2008). A strong demand for systematically integrating sustainability into higher education is emerging in the universities and this is now reflected in teaching, research, operations, assessment and reporting (Lozano et al., 2015). However, very few universities have developed special programmes to support sustainable development to date (Geier \& Fichter, 2015). Sri Lanka's higher education scheme is considered as a great public service (Ambepitiya, 2016) as it offers free university education to those youth who obtain very high Z-Scores at the General Certificate of Examination Advanced Level.

A research done by McGowan et al. (2015) suggested that social and human capital constraints often tended to limit the prospects of young women business owners who wished to emerge as entrepreneurial leaders. Their findings suggest that many young women have inadequate social and human capital-based resources and that such deficits have a negative impact on the development effectiveness of their businesses. The preparations made in the early stage to initiate new ventures will have to be backed up by competence, the right attitude and innovation ability to overcome the inevitable challenges. Women who are successful can offer meaningful employment to others while they are economically rewarded; if they have been properly trained, they will also run the business in a socially responsible and environmentally benign manner (Nsengimana et al., 2017). Universities should therefore develop 
the students' entrepreneurial competence, induce attitudinal change, teach innovation skills and channel their energies to realize the goals of entrepreneurial education.

H1: There is a positive relationship between (a) Entrepreneurial Competence, (b) Attitudes, (c) Innovation ability of female undergraduates and (d) Sustainable entrepreneurship career.

Presently in Sri Lanka, Mathematics, Engineering and Technology graduates are recruited by high-tech firms and Science graduates are offered employment in the government services as medical officers, teachers and technical personnel. This leaves out the majority of Management students who are the targets of the university programmes on entrepreneurial development (Bae et al., 2014). This indicates that there is a gap in the literature, as this population may differ from others in selecting an entrepreneurial career. This difference is based on the content of the subject and the theory of social identity (Obschonka et al., 2012). Management students receive more education on business related topics than students who pursue other streams (Maresch et al., 2016), so the latter have only a low chance to improve their Entrepreneurial Competence, Attitudes and Innovation skills. This may cause the relationship between Entrepreneurial Competence, Attitudes and Innovation skills and Sustainable Entrepreneurship career goal to weaken.

H2: The higher the Sustainable Entrepreneurship career goal of female undergraduates, the stronger the positive impact of Sustainable Entrepreneurial Education, which may differ according to the type of study.

Another important collective element related to the notion of entrepreneurship is entrepreneurial competencies. As Bikse (2011) defined it, entrepreneurial competence is the totality of an individual's personal abilities, qualities and skills that ensure successful entrepreneurship. Sustainable development competence includes systems thinking competence, embracing interdisciplinarity, foresighted thinking, normative competence, action competence, interpersonal competence, strategic management competence and entrepreneurial self-efficacy (Lans et al., 2014); competence in several areas is needed for establishing a new enterprise and incorporating practical ideas into its successful development. It is a significant fact that there were 18,369 female students who were able to gain university admission in the academic year 2015/2016 in Sri Lanka (University Grants Commission, 2016). This is a $15 \%$ increase over the previous year (2014/2015) in which 15,963 female students were admitted. An individual's entrepreneurial competencies were found to be related to that person's entrepreneurial success (Baron \& Markman, 2003). Not surprisingly, entrepreneurship competencies are positively influenced by entrepreneurship education. For example, Muñoz et al. (2011) have pointed out that entrepreneurship education develops the skill in a student that enables him/her to identify business opportunities. In addition to teaching about opportunity recognition, these programmes would do well to address and advice on the lifestyle decisions that can impede or facilitate new venture success (Winn, 2005). Although the universities are recognized as knowledge producers, conservators and disseminators in the traditional sense (Ozgula \& Kunday, 2015), they need to keep themselves updated on the trends in the professional fields.

H3: Sustainability-driven Entrepreneurial education positively impacts on the entrepreneurial competence of female undergraduate students, allowing them to follow a sustainable entrepreneurship career.

Entrepreneurship education consists of a programme or process of education for the development of entrepreneurial attitudes (Fayolle et al., 2006, p. 702). Developing entrepreneurship skills through education has a moderately long history and it has now become a widespread phenomenon (Kuratko, 2005). Though it is not a new field it requires further attention to enhance the quality. Another point is that there are different types of entrepreneurship education targeted at particular stages of development (Bridge et al., 1998; Gorman et al., 1997). There are also different levels of entrepreneurial education programmes that are aimed at specific groups (Liñán, 2004). For example, programmes like specialized entrepreneurship undergraduate degree programmes for enhancing the skills of students who have no experience of starting a business. The purpose of this entrepreneurial education is to teach students to develop entrepreneurial skills and to assist them in choosing a career. Some programmes are designed to further encourage those who are already qualified and possess some professional experience. Most university-level programmes offered under the Management or Business streams are intended to increase entrepreneurial awareness and to prepare aspiring entrepreneurs to face all challenges. However, if the goal of these programmes is to be realized fully, the entrepreneurship skills they impart to students must be customized to meet the actual needs of the economy. 
Development of personal qualities and attitudes is required of anyone involved in any educational programme and the purpose of sustainable entrepreneurship education is to create entrepreneurs to fulfill the social, economic and environmental needs of the country. Entrepreneurial education improves not only the student's business skills but his/her personality (Premand et al., 2016). An undergraduate is usually not aware of how to create new ventures and does not even possess the functional tools to enable him/her to do so. He/she may be equipped with a set of personal attitudes and competencies that enable him to see opportunities in the future though (Kirby, 2007). It is the function of the programme to unleash the hidden potential in the person. To ensure this, the entrepreneurship education may need to encompass a whole range of subject areas and settings and integrate them into the curriculum (Bikse \& Riemere, 2013). This education is mainly driven by participation in the entrepreneurship track programmes that include coaching and training (Premand et al., 2016). Training programmes in entrepreneurship have usually proved successful as the means to promote knowledge-based entrepreneurship and new business venture creations (Karhunen et al., 2008). Stamboulis \& Barlas (2014) found that there is a possible effect that entrepreneurial programmes have on the students' perception and that they tend to change their attitudes for the better. To develop students as entrepreneurs, the education must create an environment that encourages students to enhance their personal qualities, change their attitudes and develop the required personal skills.

H4: Sustainability-driven Entrepreneurial education positively impacts on the attitudes of female undergraduate students, driving them to select sustainable entrepreneurship career.

At the individual level, surveys have demonstrated that employees with more advanced degrees working in new technology firms are associated with higher levels of innovation (Sullivan \& Marvel, 2011; Fichter, 2016). This includes not only the introduction of new products and services, but also covers the establishment of new production methods, new sources of supply, new consumer markets, and new methods of organization. The innovation creation is a gendered process with systematic differences in individual education type (Marvel et al., 2015). Therefore, the universities can incorporate innovation-based projects and activities based on the differences in gender. Some disciplines like science and engineering provide hands-on experience in innovations. Engineering students who engage in entrepreneurial activities focus on creativity and innovation (Astebro et al., 2012). The support received from external organizations to further refine the university level programmes is yet to be measured. The emphasis on sustainability-driven and gender focused education opens a new path for the future women entrepreneurs.

H5: Sustainability-driven Entrepreneurial education positively impacts on the innovation ability of female undergraduate students encouraging them to select sustainable entrepreneurship career.

\section{Methodology:-}

To assess which type of entrepreneurial education is effective at improving sustainability-driven entrepreneurial competencies and skills of female students who enrolled for STEM and Management streams of university programmes, the results from previous studies have been used as secondary data to obtain combined measures of variables. The primary data being collected through a structured questionnaire. According to the findings of Kuckertz \& Wagner (2010), entrepreneurial education can positively impact on the students' pro-entrepreneurial attitudes and competencies. Their findings prompted this study to investigate how sustainable entrepreneurial competence, attitudes, and innovation skills impact on the selection of a sustainable entrepreneurial career. To answer the research questions on the experiences that sustainability-driven entrepreneurial education delivers to female students in the STEM and Management fields, empirical data were gathered from those students who were in 3rd learning year.

The sample was comprised of female undergraduates who were enrolled under arts, engineering, and science fields (Kuratko, 2005). The total population of the sample represented 3110 female students (from the Management and Commerce faculties) and 5845 female students (from the Medicine, Dental Surgery, Veterinary Medicine, Agriculture, Science, Indigenous Medicine, Paramedical Studies, Engineering and IT Faculties), all of whom were recruited in the year 2015. Following the suggestion of Peduzzi et al., (1996), 622 female students from Management and 1169 female students from STEM fields were included in the sample. An online survey was conducted with the respondents, and the information obtained was distributed among the student associations.

To select the sample, simple random sampling method was used for the purpose of generalizing the results among the population of female undergraduates who represented the Science, Technology, Engineering, Mathematics and Management fields. As this study is an empirical analysis of the cross-sectional data collected (Lindell \& 
Karagozoglu, 1997) and the key variables are self-reported, the threat of common method bias (CMB) cannot be discounted. CMB refers to the drawing of false conclusions as a result of low variances and this is often due to not representing the construct of the measurement (Podsakoff et al., 2003). This study took precautions to avoid CMB by applying the suggestions of Podsakoff et al. (2003). Based on the sample representation of the characteristics of the population, the authors prevented the external factors from influencing the respondents as this could cause them to delay or stop responding to the questionnaire on time; this behaviour is known as nonresponse bias as suggested by Rogelberg \& Stanton (2007). The questionnaire was distributed online via the student associations in the middle of a term. The student association of each faculty took the responsibility of collecting and returning the completed questionnaires.

Table 01:-Correlations

\begin{tabular}{|c|c|c|c|c|c|c|c|}
\hline & (1) & (2) & (3) & (4) & $(5)$ & (6) & $(7)$ \\
\hline \multicolumn{8}{|l|}{ (1) Age } \\
\hline (2) Year of Entrance & $0.16 *$ & & & & & & \\
\hline (3) Parent owner-manager & $-0.09 *$ & 0.00 & & & & & \\
\hline (4) Entrepreneurial Competence & $\begin{array}{c}0.35^{*} \\
*\end{array}$ & $\begin{array}{c}0.38^{*} \\
*\end{array}$ & $\begin{array}{c}0.31 * \\
*\end{array}$ & & & & \\
\hline (5) Attitudes & $\begin{array}{c}0.47 * \\
*\end{array}$ & $\begin{array}{c}0.30^{*} \\
*\end{array}$ & $\begin{array}{c}0.48 * \\
*\end{array}$ & $\begin{array}{c}0.64 * \\
*\end{array}$ & & & \\
\hline (6) Innovation Skills & $\begin{array}{c}0.44 * \\
*\end{array}$ & $\begin{array}{c}0.56^{*} \\
*\end{array}$ & $\begin{array}{c}0.44 * \\
*\end{array}$ & $\begin{array}{c}0.28 * \\
*\end{array}$ & $\begin{array}{c}0.42 * \\
*\end{array}$ & & \\
\hline $\begin{array}{l}\text { (7) Sustainability-driven Entrepreneurship } \\
\text { Education }\end{array}$ & $\begin{array}{c}0.36^{*} \\
*\end{array}$ & $\begin{array}{c}0.31 * \\
*\end{array}$ & $\begin{array}{c}0.45^{*} \\
*\end{array}$ & $\begin{array}{c}0.37 * \\
*\end{array}$ & $\begin{array}{l}0.42 * \\
*\end{array}$ & $\begin{array}{c}0.30^{*} \\
*\end{array}$ & \\
\hline (8) Sustainable Entrepreneurship Career & $\begin{array}{c}0.32 * \\
*\end{array}$ & $\begin{array}{c}0.37 * \\
*\end{array}$ & $\begin{array}{c}0.34 * \\
*\end{array}$ & $\begin{array}{c}0.30 * \\
*\end{array}$ & $\begin{array}{c}0.31 * \\
*\end{array}$ & $\begin{array}{c}0.35^{*} \\
*\end{array}$ & $\begin{array}{c}0.28 * \\
*\end{array}$ \\
\hline $\begin{array}{l}\text { Note. } \mathrm{M}=\text { mean, } \mathrm{N}=1791 \text {, } \\
* \mathrm{p}<.05, * * \mathrm{p}<.0 .1 . \\
\text { Source: Survey data }\end{array}$ & & & & & & & \\
\hline
\end{tabular}

Descriptive statistics suggest that there is little difference between STEM and Management students. The fundamental difference is that the female management students have a higher level of sustainability-driven entrepreneurial education (Table 01). The chosen analysis method is logistic regression, a stepwise method, in which the following control variables, direct link variables and moderators were entered in stepwise. These analyses were conducted in two stages, once for STEM female students and once for Management female students.

\section{Operationalization}

As the dependent variable, Sustainable Entrepreneurship career goal was measured with a 7-point Likert scale, ranging 1-Disagree strongly, 2-Disagree moderately, 3-Disagree a little, 4-Neither disagree nor agree, 5-Agree a little, 6-Agree moderately and 7-Agree strongly. The measures applied here are based on the entrepreneur ladder presented by Van et al (2012). Sustainability-Driven Entrepreneurial Education was measured by the number of internal or external university programmes offered by the faculties in the fields of Management, Engineering, Science and Technology. These programmes included opportunity recognition, business planning, creativity \& innovation skills, marketing practices and other allied topics. Using the self-reported questionnaire, the authors compared female students from the Management stream to female students from the STEM streams. Entrepreneurial attitudes were measured by using a 5-point Likert scale and a single factor explains $79.81 \%$ of the variance with a Cronbach's alpha of 0.825 , which shows high internal consistency. The measurement of Entrepreneurial competence was made on a 7-point scale to capture the degree of preparation of the respondents for starting a sustainable business. Its single factor explains $81.31 \%$ of the variance with a Cronbach's Alpha of 0.923 . To assess the Innovation Skills (Sullivan \& Marvel, 2011), a four-item, five-point, innovation scale was used. The single factor explains $71.68 \%$ of the variance with a Cronbach alpha of 0.801 . Age, year of entrance and parent owner-manager were selected as the control variables. 
Figure 01:-Conceptual Model

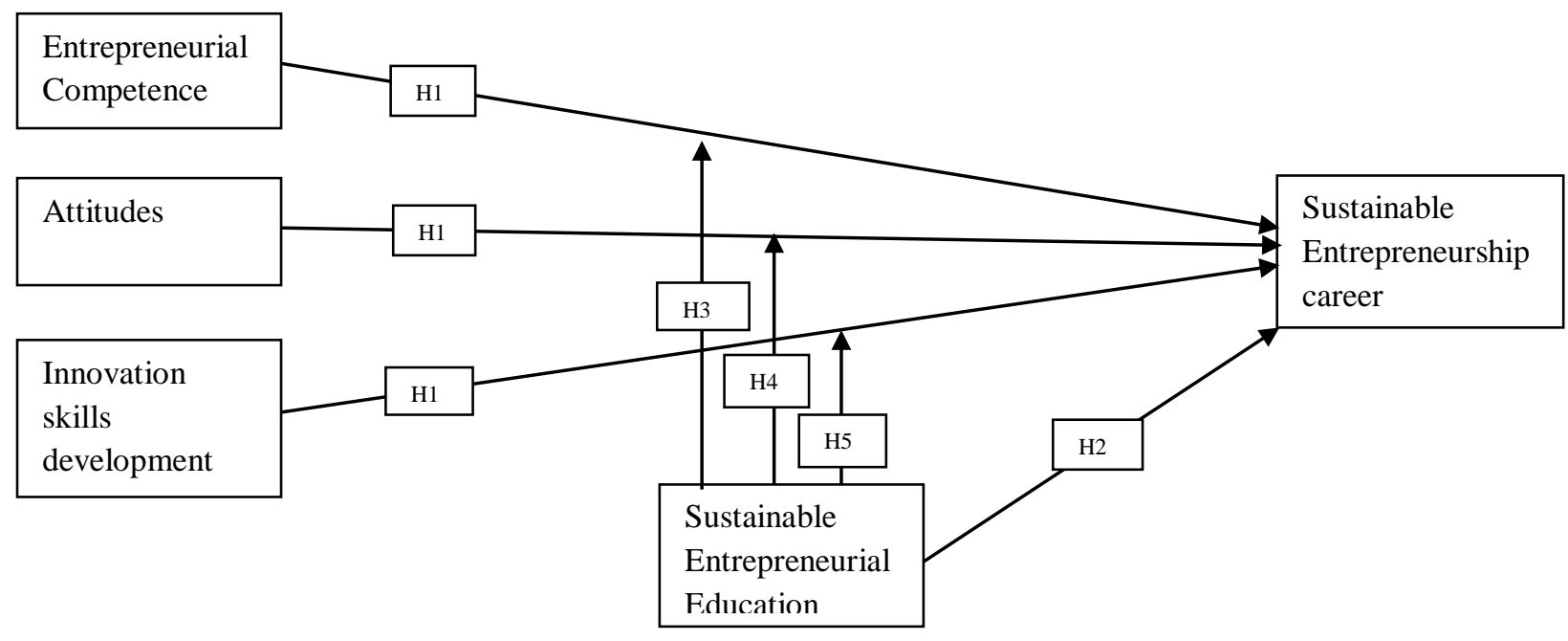

\section{Results:-}

Source: Developed by the authors

Logistic regression was applied as the dependent variable was highly skewed. In the stepwise approach two steps were conducted, with the control variables entered first, then the direct relationship between entrepreneurial competence, innovation skills and attitudes for sustainable entrepreneurship career were entered. Finally, moderation was assessed with two-way interaction of centered variables.

The summarized results of the analysis are presented in Table 01,02 and 03 . Table 01 reveals that there is a positive relationship between the independent variables. They correlate from small to medium with each other. Entrepreneurial competence and Attitudes are significantly positive, and correlated with innovation skills. Those who have started Sustainable entrepreneurial education in the second year tend to score higher on Entrepreneurial competence, Attitudes and Innovation skills.

The results in Table 02 are based on $\mathrm{R}^{2}$ values and the percentage of classified cases, which indicate a good model fit. An increase in $\mathrm{R}^{2}$ values and the percentage of classified cases in step one, step two and step three show the independent variables' significant contribution to the sustainability entrepreneurship career. The age limit to enter Sri Lankan state universities ranges from age 21 to age 24. Taking the age and the year of entrance to the entrepreneurial education as control variables, the results reveal that at 23 years of age, female students in the second year have a higher chance of following a Sustainability entrepreneurship career. However, parent ownermanager has a low degree of Sustainable entrepreneurship career. According to Table 03, Entrepreneurial competence, Attitudes and Innovation skills have positively influenced the Sustainable entrepreneurship career, which proves hypothesis H1. This is in line with the previous findings on entrepreneurial career. Entrepreneurial competence is positively related to Sustainable entrepreneurship career for both STEM and Management female students and is significant for the whole group. This proves H3. Attitudes are also positively related to Sustainable entrepreneurship career for both STEM and Management female students and significant for the whole group. This supports hypothesis H4 and is in line with the findings of Maresch et al., (2016). Innovation skills are positively related to Sustainable entrepreneurship career for both STEM and Management female students but there is no significant relationship in the case of Management female students. This supports H5 and partially supports H2.

Table 02:-Moderated Regression - Results

\begin{tabular}{|l|c|c|c|c|c|c|}
\hline \hline & \multicolumn{2}{|c|}{$\begin{array}{c}\text { Full Sample } \\
\text { N=1791 }\end{array}$} & \multicolumn{2}{c|}{$\begin{array}{c}\text { STEM Students } \\
\text { N=1169 }\end{array}$} & \multicolumn{2}{c|}{$\begin{array}{c}\text { Management } \\
\text { Students N=622 }\end{array}$} \\
\hline & B & Sig & B & Sig & B & Sig \\
\hline Step 01 & & & & & & \\
\hline Constant & -0.801 & 0.000 & -0.376 & 0.564 & -0.876 & 0.789 \\
\hline
\end{tabular}




\begin{tabular}{|c|c|c|c|c|c|c|}
\hline Age & 0.46 & 0.000 & 0.43 & 0.163 & 0.35 & 0.486 \\
\hline Year of Entrance & 0.486 & 0.000 & 0.324 & 0.387 & 0.256 & 0.076 \\
\hline Parents owner-manager & -0.321 & 0.000 & -0.221 & -0.137 & -0.0678 & 0.000 \\
\hline \multirow[t]{2}{*}{ C\&S-R ${ }^{2}$; Nagelk. R ${ }^{2} ; \%$ Corr.Class. } & 030;041; & & $039 ; 043$ & & 049;061 & \\
\hline & $61.2 \%$ & & $74.0 \%$ & & $74.2 \%$ & \\
\hline \multicolumn{7}{|l|}{ Step 02} \\
\hline Constant & -1.397 & 0.000 & -0.853 & 0.211 & -1.456 & 0.004 \\
\hline Age & 0.48 & 0.000 & 0.44 & 0.136 & 0.46 & 0.002 \\
\hline Years of Entrance & 0.389 & 0.000 & 0.357 & 0.235 & 0.276 & 0.000 \\
\hline Parents owner-manager & -0.254 & 0.000 & -0.344 & 0.219 & -0.537 & 0.000 \\
\hline Entrepreneurial Competence & 0.335 & 0.000 & 0.458 & 0.000 & 0.464 & 0.000 \\
\hline Attitudes & 0.431 & 0.000 & 0.460 & 0.006 & 0.652 & 0.000 \\
\hline Innovation Skills & 0.358 & 0.000 & 0.644 & 0.009 & 0.752 & 0.964 \\
\hline $\begin{array}{l}\text { Sustainability-driven Entrepreneurship } \\
\text { Education }\end{array}$ & 0.088 & 0.000 & 0.95 & 0.000 & 0.651 & 0.000 \\
\hline SEE*EC & 0.000 & 0.006 & 0.543 & 0.067 & 0.000 & 0.024 \\
\hline SEE*Attitudes & 0.002 & 0.003 & 0.000 & 0.024 & 0.654 & 0.000 \\
\hline SEE*IS & 0.001 & 0.005 & 0.045 & 0.000 & 0.000 & 0.435 \\
\hline C\&S-R ${ }^{2}$; Nagelk. R ${ }^{2} ; \%$ Corr.Class. & $276 ; 387$ & 0.000 & $208 ; 387$ & & $298 ; 405$ & \\
\hline & $72.3 \%$ & & $76.5 \%$ & & $78.3 \%$ & \\
\hline
\end{tabular}

Source: Survey data

Based on the selected entrepreneurial competence (Lans et al., 2014), factors such as System thinking competence, Willingness to embrace diversity and interdisciplinarity, Foresighted thinking, Normative competence, Action competence, Interpersonal competence and Strategic management competence were analyzed to identify which of those mainly influenced sustainability-driven entrepreneurial education. Strategic management competence is highly developed in both STEM and Management female students. Action competence is higher in Management female students than STEM female students. Embracing diversity and interdisciplinarity, System thinking competence and Foresighted thinking resulted in higher influence, but normative thinking showed a lower influence on sustainability-driven entrepreneurship education for both STEM and Management female students. The influence of interpersonal competence is higher for the whole group, but it is weak for the STEM female students. Therefore, descriptive statistics show there are few differences between STEM and Management female students despite Management female students having a higher degree of Sustainability-driven entrepreneurial education.

\begin{tabular}{|c|c|c|c|c|c|c|c|}
\hline & \multicolumn{2}{|c|}{$\begin{array}{c}\text { Full } \\
\text { Sample } \\
\mathrm{N}=1791\end{array}$} & \multicolumn{2}{|c|}{$\begin{array}{c}\text { STEM } \\
\text { Students } \\
\mathrm{N}=1169\end{array}$} & \multicolumn{2}{|c|}{$\begin{array}{c}\text { Managem } \\
\text { ent } \\
\text { Students } \\
\mathrm{N}=622\end{array}$} & \multirow[t]{2}{*}{$\begin{array}{l}\text { Dif } \\
\text { f. }\end{array}$} \\
\hline & $\begin{array}{c}\mathrm{Me} \\
\text { an }\end{array}$ & SD & $\begin{array}{c}\mathrm{Me} \\
\text { an }\end{array}$ & SD & $\begin{array}{c}\mathrm{Me} \\
\text { an }\end{array}$ & SD & \\
\hline \multicolumn{8}{|l|}{ Control Variables } \\
\hline Age & $\begin{array}{c}23.4 \\
5\end{array}$ & $\begin{array}{c}1.5 \\
4\end{array}$ & $\begin{array}{c}23.7 \\
6\end{array}$ & $\begin{array}{c}1.5 \\
4\end{array}$ & $\begin{array}{c}23.3 \\
2\end{array}$ & $\begin{array}{c}1.6 \\
7\end{array}$ & \\
\hline Year of Entrance & 2.35 & $\begin{array}{c}0.5 \\
4\end{array}$ & 2.45 & $\begin{array}{c}0.4 \\
6\end{array}$ & 2.49 & $\begin{array}{c}0.6 \\
3\end{array}$ & \\
\hline Parents owner-manager & 2.56 & $\begin{array}{c}0.2 \\
1 \\
\end{array}$ & 2.21 & $\begin{array}{c}0.3 \\
5 \\
\end{array}$ & 2.58 & $\begin{array}{c}0.3 \\
1 \\
\end{array}$ & \\
\hline Independent Variables & & & & & & & \\
\hline
\end{tabular}




\begin{tabular}{|c|c|c|c|c|c|c|c|}
\hline \multicolumn{8}{|l|}{ Attitudes } \\
\hline $\begin{array}{l}\text { Being a sustainable entrepreneur would bring more benefits than } \\
\text { being employed elsewhere }\end{array}$ & 6.23 & $\begin{array}{c}1.4 \\
3\end{array}$ & 5.76 & $\begin{array}{c}1.5 \\
1\end{array}$ & 6.89 & $\begin{array}{c}1.8 \\
9\end{array}$ & \\
\hline Sustainable Entrepreneurship is an attractive career & 5.51 & $\begin{array}{c}1.6 \\
5\end{array}$ & 6.46 & $\begin{array}{c}1.6 \\
7\end{array}$ & 6.45 & $\begin{array}{c}1.3 \\
6\end{array}$ & $* *$ \\
\hline I will collect all resources to become a Sustainable Entrepreneur & 6.12 & $\begin{array}{c}1.7 \\
2\end{array}$ & 6.32 & $\begin{array}{c}1.9 \\
7\end{array}$ & 6.63 & $\begin{array}{c}1.1 \\
3\end{array}$ & \\
\hline Being a Sustainable Entrepreneur would bring me great satisfaction & 6.44 & $\begin{array}{c}1.2 \\
9\end{array}$ & 6.51 & $\begin{array}{c}1.2 \\
9\end{array}$ & 6.73 & $\begin{array}{c}1.8 \\
7\end{array}$ & \\
\hline \multicolumn{8}{|l|}{ Innovation Skills } \\
\hline $\begin{array}{l}\text { Learned new knowledge of various technologies important for starting } \\
\text { a business }\end{array}$ & 3.13 & $\begin{array}{c}1.0 \\
9\end{array}$ & 3.41 & $\begin{array}{c}1.5 \\
4\end{array}$ & 2.32 & $\begin{array}{c}1.4 \\
1\end{array}$ & \\
\hline $\begin{array}{l}\text { Learned new knowledge of a technology that is central to start a } \\
\text { business }\end{array}$ & 4.98 & $\begin{array}{c}1.3 \\
7\end{array}$ & 4.83 & $\begin{array}{c}1.4 \\
5\end{array}$ & 2.86 & $\begin{array}{c}1.4 \\
6\end{array}$ & \\
\hline Learned new knowledge of a technology that is novel to the public & 4.32 & $\begin{array}{c}1.2 \\
8\end{array}$ & 4.91 & $\begin{array}{c}1.4 \\
7\end{array}$ & 2.98 & $\begin{array}{c}1.2 \\
3\end{array}$ & \\
\hline $\begin{array}{l}\text { Obtained hands-on experience with a technology that is important for } \\
\text { starting a business }\end{array}$ & 4.87 & $\begin{array}{c}1.5 \\
1\end{array}$ & 4.42 & $\begin{array}{c}1.5 \\
4\end{array}$ & 3.87 & $\begin{array}{c}1.3 \\
5\end{array}$ & $* *$ \\
\hline \multicolumn{8}{|l|}{ Moderator Variable } \\
\hline Sustainability-driven Entrepreneurship Education & 1.32 & $\begin{array}{c}2.4 \\
2\end{array}$ & 1.11 & $\begin{array}{c}1.3 \\
2\end{array}$ & 1.34 & $\begin{array}{c}1.5 \\
8\end{array}$ & \\
\hline \multicolumn{8}{|l|}{ Dependent Variable } \\
\hline \multicolumn{8}{|l|}{ Sustainable Entrepreneurial Career } \\
\hline $\begin{array}{l}\text { I have already started to think of selecting sustainable } \\
\text { entrepreneurship as my career }\end{array}$ & 5.76 & $\begin{array}{c}2.3 \\
2\end{array}$ & 4.76 & $\begin{array}{c}1.4 \\
2\end{array}$ & 5.72 & $\begin{array}{c}1.6 \\
5\end{array}$ & \\
\hline SD: Standard Deviation & & & & & & & \\
\hline $\begin{array}{l}* \mathrm{p}<.05 . * * \mathrm{p}<.01 . \\
\text { Source: Survey data }\end{array}$ & & & & & & & \\
\hline
\end{tabular}

Table 03:-Means and Standard Deviations of the variables

\section{Discussion and Limitation:-}

The aim of this study was to analyze the nature of sustainability-driven entrepreneurial education provided for STEM and Management female students in Sri Lanka's state universities and compare the education received by each group based on Entrepreneurial competence development, Attitude change and Innovation skills development. Sustainability-driven entrepreneurial education influenced the sustainable entrepreneurship career with the control of age, entrance year to the entrepreneurial education and the parent owner-manager conditions. This result supports the findings and theories of previous research (Fayolle et al., 2006; Lan et al., 2014; Fichter \& Tienmann, 2018) and provides useful insights for policy making on higher education to improve the existing level of sustainable entrepreneurship education.

Most importantly, this study reveals the low coefficient for sustainability-driven entrepreneurship education even though it is positive and significant. This indicates that the inputs and methods used for sustainability-driven education need to be improved. The most effective learning methods are still the subject of research while the need for improvement in sustainability-driven entrepreneurship education has been identified (Lozano et al., 2013; Hesselbarth \& Schaltegger, 2014). Female students in the Management field may receive more advantages than STEM female students, resulting in a high coefficient. Students who have previously received business education, have academic achievements, and are motivated (Maresch et al., 2016) are more likely to acquire new knowledge through Sustainable entrepreneurship education. Developing existing programmes and training students can be a big undertaking, thus improving the quality of the field will be a challenge to the universities (Robinson \& Hayes, 1991). Science, Technology, Engineering and Mathematics are the disciplines that guide students more towards 
innovation. The chance of receiving technological innovation skill is lower among Management female graduates (Table 03). This finding is in contrast to the previous research by Maresch et al., (2016) but is supported by Astebro et al. (2012). It would seem that the current level of Sustainability-driven entrepreneurial education is less effective at improving female students' innovation skills.

The effectiveness of sustainability-driven entrepreneurial education seems to be influenced by Entrepreneurial competence, Attitudes and Innovation skills (Table 03). The Sustainability-driven entrepreneurial education moderated for the whole group has proved significant. But Sustainability-driven entrepreneurial education in combination with innovation skills is more significant for STEM female students, showing that the level of innovation-based education is weak in Management female students compared to STEM students. Sustainabilitydriven entrepreneurial education and entrepreneurial competence for Management students are significant, indicating that the degree of entrepreneurial competence development is weak among STEM female students. This contrasts with the findings of Maresch et al. (2016). Anyway, it can be proved that the entrepreneurial university programmes are fairly effective at increasing the entrepreneurial competence, attitudes and innovation skills of undergraduates. However, the universities that conduct entrepreneurial development programmes need to enhance the quality and content of entrepreneurial education programmes to increase the entrepreneurial competence of female students in the STEM fields and at the same time increase the innovation skills (Fichter, 2016) of female students in the Management field. This research suggests that educators and policymakers should incorporate five strategic priorities into the strategic vision of a university education programme: excellence in education, engagement with regional industry, global understanding and engagement, justice and sustainability, and greater involvement of the academic community (Fichter \& Tieman, 2018).

Whereas the Attitudes and Sustainability-driven entrepreneurship for the whole group is significant, it reveals that the opinion of STEM and Management female students on initiating future sustainable entrepreneurship is also positive. The education has received the approval that is warranted due to the positive outcome of sustainable entrepreneurship. Despite that, one concern that has been expressed requires an explanation, which is that STEM students may be reluctant to take up sustainable entrepreneurship as their entrepreneurial competence was shown as not significant. This phenomenon can be explained by invoking social identity theory (Obschonka et al., 2012), and by understanding that Management students can create a social identity for themselves by initiating or managing organizations. This is a well-recognized condition in the Management field which is linked with support activities to implement such entrepreneurship roles as business plan competition, counseling, and mentoring start-up teams (Rothaermel et al., 2007). However, STEM female students also construct their own identity based on Science or Engineering but will not pay much attention to their entrepreneurial development although their innovation skills are significant. Thus, STEM female students may react unfavorably to the social pressure brought on them in support of sustainable entrepreneurship. This research suggests that educators should develop a suitable mechanism to counter the threats of social pressure, possibly by inculcating the central value of sustainable entrepreneurship to STEM female students.

This study was not intended to pinpoint the processes and challenges of sustainability-driven entrepreneurial education. Therefore, any future research that is conducted would do well to identify the effects of cultural and environmental factors, because the duration and family backgrounds differ with the type of study. Moreover, female students tend to have multiple goals rather than the single goal of a high-paid career, and those will include marriage and parenthood. This study has focused only on identifying females' career choice in sustainable entrepreneurship. It will also be interesting for future researchers to investigate the changing sustainable career goals of female undergraduates, some of whom want to become CEOs eventually. This will allow women to be more independent and flexible in managing their finances. As this is a gender-based study, contemporary and complementary research can be referred to see the differences between male and female students in their attitudes toward taking up sustainable entrepreneurial careers.

\section{Conclusion:-}

Universities can always do a better job by making changes to traditional education by including more entrepreneurial activities within both their internal and external academic structures (Etzkowitz et al., 2000). Universities should also persuade more female students to take up sustainable entrepreneurial courses by convincing them of the benefits of such a career choice. Most of the university centers for entrepreneurship have focused on three major areas: (1) entrepreneurial education; (2) outreach activities with entrepreneurs; and (3) entrepreneurial research (Kuratko, 2005). Sustainability entrepreneurial education consists of these areas with the focus on 
developing a business culture that balances the economic, social and environmental aspects. The results of this study provide some justifications to highlight the importance of sustainable entrepreneurship education in creating future women entrepreneurs.

One fundamental reason for establishing sustainable entrepreneurship education in both fields would be to benefit male and female students to have access to industry and networking facilities, workshops \& seminars, entrepreneurship \& innovation-based exhibitions, mentoring programmes and research opportunities. These measures will support and direct female students in both fields to engage in sustainable entrepreneurship. The findings of the survey confirm that the offered direction towards sustainable entrepreneurship will be effective for female students in STEM and Management fields at this stage. Thus, the results provide evidence of the contribution that education can make towards the acquisition of innovation skills and entrepreneur competence. Whereas female Management students generally lack skills in innovation, female STEM students are weak in sustainable entrepreneurial competence. This result implies that sustainability-driven entrepreneurial education addresses these two issues of innovation skills and entrepreneurial competence separately for STEM and Management female students. Thus, there appears to be a need for tailor-made educational programmes for the students engaged in both these fields of study.

\section{References:-}

1. Ahmed, T., Chandran, V. G. R., \& Klobas, J. E., (2017). Demographic differences in learner response to entrepreneurial education programmes in Pakistan. Educational Studies, 43(4) 464-483, DOI: 10.1080/03055698.2017.1293506.

2. Ambepitiya, K.R. (2016). Employability of Graduates of Public and Private Management Education Institutes: A Case Study of Two Institutes in Sri Lanka. Open University Sri Lanka Journal, 11,113134. DOI: http://doi.org/10.4038/ouslj.v11i0.7346.

3. Astebro, T., Bazzazian, N., \& SBraguinsky, S. (2012). Startups by recent university graduates and their faculty: implications for university entrepreneurship policy. Research Policy, 41,663-677.

4. Bae, T.J., Qian, S., Miao, C., \& Fiet, J.O. (2014). The relationship between Entrepreneurship Education and Entrepreneurial Intention: A meta Analytical Review. Entrepreneurship Theory and Practice, 38, 217-254.

5. Baron, R.A., \& Markman, G.D. (2003). Beyond social capital: the role of entrepreneurs' social competence in their financial success. Journal of Business Venturing, 18, 41-60.

6. Bridge, S., O’Neill, K., \& Cromie, S. (1998). Understanding enterprise, entrepreneurship and small firms. London: Macmillan.

7. Bikse, V., \& Riemere, I. (2013). The development of entrepreneurial competencies for students of mathematics and the science subjects: the Latvian experience. World Conference on Psychology and Sociology 2012. Procedia - Social and Behavioral Sciences 82,511 - 519.

8. Cooper, S., \& McGowan, P. (2009). Facilitating technology entrepreneurship through experiential learning: the role of university-based business plan competitions. Conference proceedings of $32^{\text {nd }}$ ISBE Policy and Research Conference. Liverpool, United Kingdom.

9. Davidsson, P. (2008). "The entrepreneurship research challenge". Edward Elgar, Cheltenham.

10. Etzkowitz, H., Webster, A., Gebhardt, C., \& Terra, B.R.C. (2000). The future of the university and the university of the future: evolution of ivory tower to entrepreneurial paradigm. Research Policy, 29, 313-330. https://doi.org/10.1016/S0048-7333(99)00069-4.

11. Fayolle, A., Gailly, B., \& Lassas-Clerc, N. (2006). Assessing the impact of entrepreneurship education programmes: A new methodology. Journal of European Industrial Training, 30(9), 701-720.

12. Fayolle, A., \& Gaill,y B. (2015). The impact of entrepreneurship education on entrepreneurial attitudes and intention: Hysteresis and persistence. Journal of Small Business Management, 53(1), 75-93. DOI: $10.1111 /$ jsbm. 12065 .

13. Fichter, K., \& Tiemann, I. (2018). Factors influencing university support for sustainable entrepreneurship: insights from explorative case studies. Journal of Cleaner Production. 175, 512-524.

14. Fichter, K., \& Clausen, J. (2016). Diffusion dynamics of sustainable innovation - insights on diffusion patterns based on the analysis of 100 sustainable product and service innovations. Journal of Innovation Management, 4, $30-67$.

15. Geier, J., \& Fichter, K. (2015). "Good practice profiles: activities in sustainable entrepreneurship at universities in Finland, Germany, Sweden, the United Kingdom and the United States". Borderstep Institut für Inno vation und Nachhaltigkeit, Berlin. 
16. Gorman, G., Hanlon, D., \& King, W. (1997). Some research perspectives on entrepreneurship education, enterprise education and education for Small Business Management: A ten-year literature review. International Small Business Journal, 15(3), 56-77.

17. Henry, C., Baillie, S., \& Treanor, L. (2015). "Chapter 2 Encouraging women's entrepreneurship in the sciences: Women in veterinary medicine" In Innovating Women: Contributions to Technological Advancement. Published online: pp. 15-33.

18. Hesselbarth, C., \& Schaltegger, S. (2014). Educating change agents for sustainability - learnings from the first sustainability management master of business administration. Journal of Cleaner Production, 62, 24-36.

19. Huan, J.Q. (2017). Digital aspirations: 'wrong-number' mobile-phone relationships and experimental ethics among women entrepreneurs in rural Bangladesh. Journal of the Royal Anthropological Institute, 24, $107-125$.

20. Karhunene, P., Ledyaeva, S., Gustafsson-Pesonen, A., Mochinikava, E., \& Vasikenko,D. (2008). Russian students' perception of entrepreneurship. "Results of a survey in three St. Petersburg Universities", Entrepreneurship Development - Project 2. HSE Mikkeli Business Campus Publications. HSE Print: Moscow.

21. Kirby, D. (2007). Changing the entrepreneurship education paradigm. In A. Fayolle (Ed.), Handbook of research in entrepreneurship education (pp. 21 - 33). Cheltenham, UK Northampton, MA: Edward Elgar Publishing.

22. Kuratko, D.F. (2005). The emergence of entrepreneurship education: Development, trends, and challenges. Entrepreneurship Theory and Practice, 29(5), 577-598.

23. Kuckertz, A., \& Wagner, M., (2010). The influence of sustainability orientation on entrepreneurial intentions investigating the role of business experience. Journal of Business Venture, 25,524-539.

24. Lan, T., Blok, V., \& Wesselink, R. (2014). Learning apart and together: towards an integrated competence framework for sustainable entrepreneurship in higher education. Journal of Cleaner Production, 62,37-47.

25. Liñán, F. (2004). Intention-based models of entrepreneurship education. Piccola Impresa/Small Business, 3, 1135.

26. Lindell, M., \& Karagozoglu, N. (1997). Global strategies of us and scandinavian r\&d- intensive-small- and medium- sized companies. European Management Journal, 15,135-147.

27. Lozano, R., Ceulemans, K., Alonso-Almeida, M., Huisingh, D., Lozano, F.J., Waas, T., Lambrechts, W., Lukman, R., \& Hugé, J. (2015). A review of commitment and implementation of sustainable development in higher education: results from a worldwide survey. Journal of Cleaner Production. 108, 1-18. https://doi.org/10.1016/j.jclepro.2014.09.048

28. Lozano, R., Lozano, F.J., Mulder, K., Huisingh, D., \& Waas, T. (2013). Advancing higher education for sustainable development: international insights and critical reflections. Journal of Cleaner Production. 48, 3-9. https://doi.org/10.1016/j.jclepro.2013.03.034

29. Maresch, D.,Harms,R., Kailer,N., \& Wimmer,B. (2016). The impact of entrepreneurship education on the entrepreneurial intention of students in science and engineering versus business studies university programs. Technological Forecasting and Social Change, 104,172-179

30. Marvel, M.R., Lee, I.H., \& Wolfe, M.T. (2015). Entrepreneur gender and firm innovation activity: a multilevel perspective. IEEE Transaction on Engineering Management, 62(4).558-567.

31. McGowan, P., Cooper, S., Durkin, M., \& O'Kane, C. (2015). The influence of social and human capital in developing young women as entrepreneurial business leaders. Journal of Small Business Management, 53(3), 645-661.

32. Muñoz, C.C.A., Mosey, S., \& Binks, M. (2011). Developing opportunity-identification capabilities in the Classroom: visual evidence for changing mental frames. Academy of Management Learning \& Education, 10,277-295.

33. Nsengimana, S.,Tengeh, R.K., \& Iwu, C.G. (2017). The sustainability of businesses in Kigali, Rwanda: an analysis of the barriers faced by women entrepreneurs. Sustainability, 9(8), 1372.

34. Obschonka, M., Goethner, M., Silbereisen, R.K., \& Cantner, U. (2012). Social identity and the transition to entrepreneurship: the role of group identification with workplace peers. Vocational Behaviour, 80,137-147.

35. Ozgula, U., \& Kundaya, O. (2015). Conceptual development of academic entrepreneurial intentions scale. World Conference on Technology, Innovation and Entrepreneurship. Procedia - Social and Behavioral Sciences, 195, $881-887$.

36. Peduzzi, P., Concato, J., Kemper E., Holford, T,R., \& Feinstein, A.R. (1996). A simulation study of the number of events per variable in logistic regression analysis. Journal of Clinical Epidemiology, 49,1373-1379.

37. Podsakoff, P.M., Mackenzie,S.B., Podsakoof, N.P., \& Lee,J-Y. (2003). Common method biases in behavioural research: a critical review of the literature and recommended remedies. Journal of Applied Psychology, 88,879903. 
38. Premand, P., Brodmann, S., Almeida, R., Grun, R., \& Barouni,M. (2016). Entrepreneurship education and entry into self-employment among university graduates. World Development, 77,311-327. DOI:dx.doi.org/10.1016.worlddev.2015.08.028

39. Ramos, T.B., Caeiro, S., Van Hoof, B., Lozano, R., Huisingh, D., \& Ceulemans, K. (2015). Experience from the implementation of sustainable development in higher education institutions: Environmental Management for sustainable universities. Journal of Cleaner Production, 106, 3-10. https://doi.org/10.1016/j.jclepro.2015.05.110.

40. Rauch, A.J., \& Hulsink, W. (2015). Putting entrepreneurship education where the intention to act lies. an investigation into the impact of entrepreneurship education on entrepreneurial behavior. Academy of Management Learning \& Education, 14(2),1-49. DOI: http://dx.doi.org/ 10.5465/amle.2012.0293.

41. Robinson, P., \& Hayes, M. (1991). Entrepreneurship education in America's major universities. Entrepreneurship Theory and Practice, 15(3), 41-52.

42. Rogelberg, S.G., \& Stanton, J. (2007). Introduction: Understanding and dealing with organizational survey nonresponse. Organizational Research Methods, 10,195-209.

43. Rose, G., Ryan, K., \& Desha, C. (2015). Implementing a holistic process for embedding sustainability: a case study in first year Engineering, Monash University Australia. Journal of Cleaner Production, 106, $229-238$. DOI: http://dx.doi.org/10.1016/j.jclepro.2015.02.066.

44. Schmitt-figueiro, P., \& Raufflet. E. (2015). Sustainability in higher education: A systematic review with focus on Management Education. Journal of Cleaner Production. 106, 22-33. DOI: http://dx.doi.org/10.1016/j.jclepro.2015.04.118.

45. Shinnar, R.S., Hsu, D.K., Powell, B.C., \& Zhou,H. (2018). Entrepreneurial intentions and start-ups: are women or men more likely to enact their intentions? International Small Business Journal: Researching Entrepreneurship, 36(1) $60-80$.

46. Stamboulis, Y., \& Barlas, A. (2014). Entrepreneurship impact on student attitudes. International Journal of Management Education. 12. 365-373.

47. Sullivan, D. M., \& Marvel, M.R .(2011). Knowledge acquisition, network reliance, and early-stage technology venture outcomes. Journal of Management Studies, 48.1169-1193.

48. Thursby JG, Jensen R., \& Thursby MC. (2001). Objectives, characteristics and outcomes of university licensing: A survey of major US universities. The Journal of Technology Transfer, 26(1-2),59-72.

49. Unger, J., Rauch, A., Frese, M., \& Rosenbusch, N. (2011). Human capital and entrepreneurial success: a metaanalytical review. Journal of Business Venture. 26, 341-358.

50. University Grants Commission. (2016). Undergraduate Admissions by Academic Programme and Sex (Academic Year 2015/2016). Sri Lanka University Statistics, University Grants Commission of Sri Lanka. Pp.21. Retrieved from http://www.ugc.ac.lk/en/publications/1905-sri-lanka-university-statistics-2016.html.

51. University Grants Commission. (2015). Undergraduate Admissions by Academic Programme and Sex (Academic Year 2015/2016). Sri Lanka University Statistics, University Grants Commission of Sri Lanka. Pp.21. Retrieved from http://ugc.ac.lk/en/component/content/article/1709-sri-lanka-university-statistics2015.html.

52. Winn, J. (2005). Women Entrepreneurs: Can we remove the barriers? International Entrepreneurship and Management Journal,1(3), 381-397. 